\title{
Characteristics of Soils Developing from Gabbro, Phyllite and Chert Parent Rock in Karangsambung District
}

\author{
Ratna Taher ${ }^{1 *}$, Makruf Nurudin ${ }^{2}$ and Eko Hanudin ${ }^{2}$ \\ ${ }^{1}$ Department of Soil Science, Faculty of Agriculture, Lambung Mangkurat University \\ Jln. A. Yani Km. 36 Simpang Empat Banjarbaru, South Kalimantan, 70714, Indonesia \\ ${ }^{2}$ Department of Soil, Faculty of Agriculture Universitas Gadjah Mada \\ Jln. Flora no. 1, Bulaksumur, Sleman, Yogyakarta 55281, Indonesia \\ *Corresponding author: ratnapedologi@gmail.com
}

Received: 18 ${ }^{\text {th }}$ January 2018; Revised: 29th March 2019; Accepted: $15^{\text {th }}$ October 2019

\begin{abstract}
Understanding the nature of the soil is very important to know the potential and the proper management of the soil. This study aimed to determine the differences in morphological, physical, and chemical properties of the soils developing from gabbro, phylitte and chert parent rock. The soil profile was made to represent each parent rock of gabbro, phyllite and chert located on the upper and middle slopes with pine-dominated vegetation and mixed gardens. Observation in the field is a professional description to observe soil morphology. Soil samples were taken at each horizon to analyze soil physical properties (bulk density, particle density, and texture), soil chemical properties ( $\mathrm{pH}$, exchanged cations, cation exchange capacity, available $\mathrm{P}$, organic $\mathrm{C}$, and total $\mathrm{N}$ ). Texture analysis results showed that clay content of the soil developing from parent rock of Gabro 1 is the highest, followed by the soil clay content from Chert 1, Phyllite 1, Chert 2, Phyllite 2, and Gabbro 2, respectively. The order of soil acidity level $(\mathrm{pH})$ is Gabbro $2>$ Gabbro $1>$ Chert 1 $\sim$ Chert $2>$ Phyllite $1 \sim$ Phyllite 2 . Meanwhile, the order of the cation exchange capacity is Gabbro $1>$ Gabbro $2>$ Phyllite $1>$ Chert $1>$ Phyllite $2>$ Chert 2 , and the order of the base saturation is Chert $2>$ Gabbro $2>$ Chert $1>$ Phyllite $2>$ Phyllite1 $>$ Gabbro 1 .
\end{abstract}

Keywords: chert, gabbro, Karangsambung, phyllite, rock, soil properties

\section{INTRODUCTION}

Soil is a very important element of land. The socioeconomic development of any country is mainly based on land and water resources. Human population causes food needs to increase, while the availability of fertile land decreases due to the conversion of functions to non-agricultural activities (Harahsheh et al., 2015). Soil is used for various purposes, ranging from agriculture, engineering to sanitation (Zinck et al., 2016). In the field of agriculture, soil is a plant growing medium that is essential to provide several factors for plants such as nutrients and water (Paramitha et al., 2015). Plants that lack certain nutrients can experience growth disruptions, resulting in production loss (Sunarta et al., 2015). Besides nutrients, plants need water for various growth processes. In addition, plants play an important role in the water cycle on earth (Damm et al., 2018).

Soil comes from weathering of the parent soil material, while the parent soil material comes from weathering of the parent rock. Pedogenesis process runs due to the availability of the parent material and other factors in soil formation (Hardjowigeno, 1993). Regarded as passive factor in soil formation, parent rocks have a great effect since the nature of the acid or base is likely to be inherited to the soil formed. Thus, evaluating the formation of soil material is necessary to concentrate on reaction between the lithosphere and between the atmosphere and the biosphere (Paton, 1978). The influence of the properties of the parent rock on the soil properties are clearly visible in the soils in dry areas or young soils. Conversely, the influence of the properties of the parent rock on the soil properties the becomes less clear in wet areas or old soils. However, this does 
not mean that in old soils the effect of the properties of the parent rock is lost. For example, weathered quartz will still be found in mature soils (Hardjowigeno, 1993).

Kebumen Regency, Central Java is an outcrop of various types of rock. The rock outcrops studied were in Karangsambung district. Some of them are claystone, chert, schist, phyllite, gabbro, diabase, serpentine and other rocks. Until now there have not been many studies conducted on the properties of soil that developed from various types of parent rocks, especially those originating from gabbro, phyllite and chert. Understanding of the origin and soil properties is very important, so that we can know the potential and ways of managing the soil to fit its designation so that it can produce optimally and stay awake for a long time. This study aims to identify the morphology, physical and chemical properties of the soil that develops from the parent rock of gabbro, phyllite, and chert.

\section{MATERIALS AND METHODS}

\section{Research Materials and Equipment}

Materials and tools used for activities in the field include: soil, geological map, measurement device, Global Positioning System (GPS), board list, dagger, hoe, clinometer, ground drill, camera, plastic, label and rubber. Materials and tools used for analysis in the laboratory include: chemicals for the analysis of soil chemical and physical properties, oven, $\mathrm{pH}$ meters, centrifuges, and others.

\section{Research Procedure}

Observations and sampling of soil were carried out in Karangsambung District, Kebumen Regency, Central Java Province. The location of profiles was determined based on the distribution of parent rock types that refer to the geological maps. The profiles were prepared on a natural area that is not sediment basin so that it is believed that the soil is genuinely the result of in situ weathering.

Observations were made on soil morphological properties including the depth, effective depth, color, texture, structure, gravel, and rock of each horizon (A, B (solum) and C) as well as other morphological features such as the presence of spots, concretion and so on. Soil samples were dried, sifted, and analyzed according to the research objectives

\section{RESULTS AND DISCUSSION}

\section{Soil Morphology}

Soil morphology is soil properties that can be observed and studied in the field. Observations were carried out by differentiating and making boundaries between soil horizons which are the result of the process of soil formation. Observations on morphology of the soil developing from gabbro, phyllite and chert parent rock showed several different properties in horizon, color, solum thickness, texture, structure and other properties (Table 1).

Soils developing from Gabbro 1 and Gabbro 2 parent rock shows different morphological features in color, solum depth, depth and type of horizon, and texture. Soil from Gabbro 1 has moist condition with loose consistency at $\mathrm{A}, \mathrm{AB}$, and $\mathrm{Bt} 1$ horizons and firm consistency at Bt2 horizon. There are many krotovinas found in this type of soil. The condition of soil moisture developing from Gabbro 2 parent rock is moist with loose consistency at all horizons.

Soil that developed from Phyllite 1 and Phyllite 2 parent rock also shows different morphological properties in type and depth of horizon, color, texture and structure. Soil that developed from Phyllite 1 parent rock is loose at the top (A horizon) and firm at the lower horizon $(\mathrm{Bt})$ and slightly firm at $\mathrm{BC} 1$ and BC 2 horizons. Soil that developed from Phyllite 2 parent rock is loose at A horizon and slightly firm at $\mathrm{Bw}$ and $\mathrm{BC}$ horizons.

Soils that developed from Chert 1 and Chert 2 parent rock have the same color, consistency and horizon type, but other morphological properties are different, such as solum depth, horizon depth, and texture.

\section{Physical Properties of soil}

The physical properties of soil observed in this study include texture, bulk density, particle density and porosity as presented in Table 2 .

\section{Texture}

Texture indicates the relative content of variously sized particles, such as sand, silt, and clay, in the soil. Texture influences the function of the soil, the amount of water and air it holds, and the rate at which water can enter and move through soil. The results of the analysis show that the soil developing from Gabbro 1 parent rock has the highest clay 
Table 1. Morphology of the soil devekoping from gabbro, phyllite, and chert parent rock

\begin{tabular}{|c|c|c|c|c|c|c|}
\hline $\begin{array}{c}\text { Parent } \\
\text { rock }\end{array}$ & Horizon & Color & $\begin{array}{l}\text { Depth } \\
(\mathrm{cm})\end{array}$ & Structure & Texture & Margin \\
\hline \multirow{4}{*}{ Gabbro 1} & A & Dark yellowish brown (10 YR 4/6) & $0-17$ & Subangular blocky & clay & clear \\
\hline & $\mathrm{AB}$ & Dark yellowish brown (10 YR 4/6) & $17-42$ & Subangular blocky & clay & clear \\
\hline & Bt1 & Yellowish brown & $42-75$ & Subangular blocky & clay & clear \\
\hline & Bt2 & Brownish yellow (10 YR 6/6) & $75-185$ & Subangular blocky & clay & clear \\
\hline \multirow{4}{*}{ Gabbro 2} & Bw & Light yellowish brown (10 YR 6/4) & $0-14$ & crumb & sandy loam & clear \\
\hline & $\mathrm{BC} 1$ & Light yellowish brown (10 YR 6/4) & $14-39$ & crumb & sandy loam & Not clear \\
\hline & $\mathrm{BC} 2$ & Light yellowish brown (10 YR 6/4) & $39-74$ & crumb & sandy loam & clear \\
\hline & $\mathrm{BC} 3$ & Light gray (10 YR 7/2) & $74-105$ & crumb & sandy loam & clear \\
\hline \multirow{4}{*}{ Phyllite 1} & $\mathrm{~A}$ & Dark yellowish brown (10 YR 4/6) & $0-25$ & crumb & clay loam & clear \\
\hline & Bt1 & Yellowish brown (10 YR 5/8) & $25-51$ & Subangular blocky & clay & clear \\
\hline & $\mathrm{BC} 1$ & Yellowish brown (10 YR 5/8) & $51-94$ & crumb & clay loam & clear \\
\hline & $\mathrm{BC} 2$ & Brown (7.5 YR 5/4) & $94-103$ & crumb & clay loam & clear \\
\hline \multirow{3}{*}{ Phyllite 2} & $\mathrm{~A}$ & Yellowish red (5 YR 5/6) & $0-20$ & crumb & clay loam & clear \\
\hline & $\mathrm{Bw}$ & Strong brown (7.5 YR 5/6) & $20-42$ & crumb & clay loam & clear \\
\hline & $\mathrm{BC}$ & Yellowish brown (10 YR 5/8) & $42-62$ & crumb & sandy clay loam & clear \\
\hline \multirow{4}{*}{ Chert 1} & A & Dark brown (7.5 YR 3/4) & $0-20$ & crumb & clay & clear \\
\hline & Bw1 & Dark brown (7.5 YR 3/4) & $20-74$ & crumb & sandy clay & clear \\
\hline & Bw2 & Dark brown (7.5 YR 3/4) & $74-146$ & crumb & sandy clay & clear \\
\hline & Bw3 & Dark brown (7.5 YR 3/4) & $146-162$ & crumb & sandy clay & clear \\
\hline \multirow{4}{*}{ Chert 2} & A & Dark brown (7.5 YR 3/4) & $0-24$ & crumb & sandy clay loam & clear \\
\hline & Bw1 & Dark brown (7.5 YR 3/4) & $24-77$ & crumb & sandy clay loam & clear \\
\hline & Bw2 & Dark brown (7.5 YR 3/4) & $77-110$ & crumb & sandy clay loam & clear \\
\hline & Bw3 & Dark brown (7.5 YR 3/4) & $110-147$ & crumb & clay & clear \\
\hline
\end{tabular}

content, while the soil developing from Gabbro 2 parent rock contains the lowest clay content. Soil developing from Gabbro 1 parent rock contains 41$55 \%$ clay meaning that the soil has clay texture. Soil containing lots of clay has many micro pores so that the soil becomes denser and not porous. Dense soil is difficult to penetrate by the roots, thus disrupting the root growth and leading to low absorption of water, air, and nutrients from the soil (Paramitha et al., 2015). Water availability is a serious problem for plant survival and productivity and is a factor that determines sustainable agriculture (Liu et al., 2011).

\section{Bulk density}

Bulk density is the weight of dry soil mass (oven dry) per unit volume. The value of soil bulk density is directly proportional to the roughness of soil particles. The rougher the particles the higher the bulk density value.

Bulk density of the soil developing from Gabbro 1 parent rock increases at $\mathrm{AB}$ horizon because even though the clay content is high, the sand content is also high, hence the bulk density increases compared to at A horizon. Besides, there is still an effect of organic matter on A horizon. Meanwhile, the bulk density of $\mathrm{Bt} 1$ and $\mathrm{Bt} 2$ horizons has decreased due to the decreased sand content. Soil bulk density increases if the amount or content of coarse fractions in the soil also increases. Soil bulk density developing from Gabbro 2 parent rock increases from Bw horizon to $\mathrm{BC} 1$ horizon because the sand content increases while the clay content decreases. The value then decreases at $\mathrm{BC} 2$ and $\mathrm{BC} 3$ horizons due to an increase in clay content and a decrease in sand or silk content.

Bulk density of the soil developing from Phyllite 1 parent rock decreases at Bt horizon due to an increase in the clay content and a decrease in the sand content. Soil bulk density increases at $\mathrm{BC} 1$ and $\mathrm{BC} 2$ horizons because the sand content also increases with the depth of the soil. Bulk density of the soil developing from Phyllite 2 parent rock decreases at $\mathrm{Bw}$ horizon due to a decrease in the content of sand and silt fraction. Meanwhile, bulk density value increases at $\mathrm{BC}$ horizon due to a significant increase in the sand content. 
Table 2. Physical properties of soil developing from gabbro, phyllite, and chert parent rock

\begin{tabular}{|c|c|c|c|c|c|c|}
\hline Parent rock & $\begin{array}{l}\text { Depth } \\
(\mathrm{cm})\end{array}$ & Horizon & $\begin{array}{c}\text { BD } \\
\left(\text { g.cm }{ }^{-3}\right)\end{array}$ & $\begin{array}{c}\text { PD } \\
\left(\text { g.cm }{ }^{-3}\right)\end{array}$ & $\begin{array}{c}\text { Porosity } \\
(\%)\end{array}$ & Texture \\
\hline \multirow{4}{*}{ Gabbro 1} & $0-17$ & $\mathrm{~A}$ & 1.02 & 2.56 & 60 & Clay \\
\hline & $17-42$ & $\mathrm{AB}$ & 1.16 & 2.60 & 55 & Clay \\
\hline & $42-75$ & Bt1 & 1.06 & 2.58 & 59 & Clay \\
\hline & $75-185$ & $\mathrm{Bt} 2$ & 1.12 & 2.59 & 57 & Clay \\
\hline \multirow{4}{*}{ Gabbro 2} & $0-14$ & $\mathrm{Bw}$ & 1.41 & 2.65 & 47 & Sandy loam \\
\hline & $14-39$ & $\mathrm{BC} 1$ & 1.43 & 2.65 & 46 & Sandy loam \\
\hline & $39-74$ & $\mathrm{BC} 2$ & 1.33 & 2.62 & 49 & Sandy loam \\
\hline & $74-105$ & $\mathrm{BC} 3$ & 1.11 & 2.59 & 57 & Sandy loam \\
\hline \multirow{4}{*}{ Phyllite 1} & $0-25$ & $\mathrm{~A}$ & 1.07 & 2.58 & 59 & Clay loam \\
\hline & $25-51$ & $\mathrm{Bt}$ & 1.05 & 2.56 & 59 & Clay \\
\hline & $51-94$ & $\mathrm{BC} 1$ & 1.13 & 2.60 & 57 & Clay loam \\
\hline & $94-103$ & $\mathrm{BC} 2$ & 1.14 & 2.60 & 56 & Clay loam \\
\hline \multirow{3}{*}{ Phyllite 2} & $0-20$ & $\mathrm{~A}$ & 1.14 & 2.59 & 56 & clay loam \\
\hline & $20-42$ & $\mathrm{Bw}$ & 1.10 & 2.58 & 57 & clay loam \\
\hline & $42-62$ & $\mathrm{BC}$ & 1.34 & 2.62 & 49 & sandy clay loam \\
\hline \multirow{4}{*}{ Chert 1} & $0-20$ & A & 1.01 & 2.56 & 61 & Clay \\
\hline & $20-74$ & Bw1 & 1.27 & 2.61 & 51 & Sandy clay \\
\hline & $74-146$ & Bw2 & 1.38 & 2.65 & 48 & Sandy clay \\
\hline & $146-162$ & Bw3 & 1,31 & 2.61 & 50 & Sandy clay \\
\hline \multirow{4}{*}{ Chert 2} & $0-24$ & $\mathrm{~A}$ & 1.30 & 2.62 & 50 & Sandy clay loam \\
\hline & $24-77$ & Bw1 & 1.40 & 2.64 & 47 & Sandy clay loam \\
\hline & $77-110$ & Bw2 & 1.35 & 2.62 & 48 & Sandy clay loam \\
\hline & $110-147$ & Bw3 & 1.25 & 2.60 & 52 & Clay \\
\hline
\end{tabular}

Bulk density of the soil developing from Chert 1 parent rock increases with the depth up to Bw2 horizon due to the increasing sand content. Bulk density value at $\mathrm{Bw} 3$ horizon decreases even though the sand content increases. This is because the amount of very coarse sand decreases, while the content of coarse sand and sand is increasing. Bulk density of the soil developing from Chert 2 parent rock increases at Bw1 horizon because the sand content increases while the clay content decreases at this horizon. The bulk density value decreases at $\mathrm{Bw} 2$ and $\mathrm{Bw} 3$ horizons because the sand content continues to decrease, while the clay content is increasing.

\section{Particle density}

Particle density is the mass density of the total solid phase per unit volume of soil. The value of soil particle density is directly proportional to the roughness of soil particles. The more coarse the soil particles, the higher the value of soil particle density. The soil particle density is usually $2.6 \mathrm{~g} . \mathrm{cm}^{-3}$.

Particles density of the soil developing from Gabbro 1 parent rock increases at $\mathrm{AB}$ horizon because even though the clay content is high but the sand content is also high, resulting in a higher soil particle density compared to at A horizon. Besides, there is still an effect of organic matter on A horizon. Meanwhile, particle density at Bt1 and Bt2 horizons decreases due to the decreased sand content. Soil particle density increases if the amount or content of coarse fractions in the soil also increases. Particle density of the soil developing from Gabbro 2 parent rock increases from $\mathrm{Bw}$ horizon to $\mathrm{BC} 1$ horizon due to an increase in the sand content and a decrease in the clay content. The value then decreases at $\mathrm{BC} 2$ and $\mathrm{BC} 3$ horizons due to an increase in the clay content and a decrease in the sand or silt content.

Particle density of the soil develooping from Phyllite 1 parent rock decreases at Bt horizon due to an increase in the clay content and a decrease in the sand content. Soil particle density increases at $\mathrm{BC} 1$ and $\mathrm{BC} 2$ horizons since the sand content also increases with the depth. Particle density of the soil developing from Phyllite 2 parent rock decreases at Bw horizon due to a decrease in the content of sand and silt fractions. Meanwhile, soil particle density 
increases at $\mathrm{BC}$ horizon due to a large increase in the sand content.

Particle density of the soil developing from Chert 1 parent rock increases with the increasing depth up to $\mathrm{Bw} 2$ horizon because the sand content also increases. The particle density value at $\mathrm{Bw} 3$ horizon decreases even though the percentage of sand increases. This happens because the extremely coarse sand content decreases while the amount of coarse sand and medium-sized sand increases. Particle density of the soil developing from Chert 2 parent rock increases at Bw1 horizon because the sand content increases while the clay content decreases. Meanwhile, the value of particle density decreases at Bw2 and Bw3 horizons because the sand content continues to decrease, while the clay content is increasing.

\section{Porosity}

Porosity is the proportion of total pore space contained in the unit volume of soil that can be occupied by water and air so that it is an indicator of soil drainage and aeration conditions. Porous soil means that there is sufficient space for the movement of water and air.

Porosity of the soil developing from Gabbro 1 parent rock decreases from $\mathrm{A}$ horizon to $\mathrm{AB}$ horizon. The value then increases at Bt1 horizon and then decreases at Bt 2 horizon. Decreased porosity at $\mathrm{AB}$ horizon, in spite of an increase in the clay content, is due to an increase in the content of organic matter. Meanwhile, the increased porosity at Bt1 horizon and the decreased porosity at Bt horizon are due to an increase in clay content and a decrease in organic $\mathrm{C}$ content, respectively. Porosity of the soil developing from Gabbro 2 parent rock decreases at $\mathrm{BC} 1$ horizon because the clay content also decreases. The value then increases at $\mathrm{BC} 2$ and $\mathrm{BC} 3$ horizons because there is an increase in clay and organic $\mathrm{C}$ content at $\mathrm{BC} 2$ horizon and there is an increase in clay content at $\mathrm{BC} 3$ horizon.

Porosity of the soil developing from Phyllite 1 parent rock decreases at $\mathrm{BC} 1$ and $\mathrm{BC} 2$ horizons. This is due to a decrease in clay content. Porosity of the soil developing from Phyllite 2 parent rock increases at $\mathrm{Bw}$ horizon due to increased clay content. The value then decreases at $\mathrm{BC} 1$ horizon because the content of clay also decreases.

Porosity of the soil developing from Chert 1 parent rock decreases at $\mathrm{Bw} 1$ and $\mathrm{Bw} 2$ horizons because of the decreasing clay content. The value then increases at Bw3 horizon despite a decrease in the clay content because the organic $\mathrm{C}$ content increases. Porosity of the soil developing from Chert 2 parent rock varies with the depth. Soil porosity decreases at Bw1 horizon because the clay content also decreases. The value then increases at $\mathrm{Bw} 2$ and $\mathrm{Bw} 3$ horizons because the clay content also increases.

\section{Chemical Properties of Soil}

The soil chemical properties observed include $\mathrm{pH}-\mathrm{H}_{2} \mathrm{O}, \mathrm{pH}-\mathrm{KCl}$, exchangeable cations $(\mathrm{Na}, \mathrm{K}, \mathrm{Ca}$ and $\mathrm{Mg}$ ), cation exchange capacity, base saturation, available $\mathrm{P}$, organic $\mathrm{C}$ and total $\mathrm{N}$ as presented in Table 3.

\section{Soil pH}

Soil reaction $(\mathrm{pH})$ is a term for expressing an acid or base reaction in the soil. The $\mathrm{pH}$ value shows the concentration of $\mathrm{H}^{+}$ions in the soil solution. Soil $\mathrm{pH}$ value can be used as an indicator of soil chemical fertility because it can reflect nutrient availability (Hanafiah, 2005).

Soil developing from Gabbro 1 parent rock has a slightly acidic soil pH (6.0-6.4). Soil developing from Gabbro 2 parent rock is slightly acidic (6.3) to neutral (6.6). Meanwhile, the soil developing from Phyllite 1 and Phyllite 2 parent rock is acidic with a $\mathrm{pH}$ value of 5.0-5.5 and 5.0-5.3, respectively. The soil developing from Chert 1 and Chert 2 parent rock, consecutively, is acidic (5.1-5.4) to slightly acidic (5.7-6.2) and acidic with $\mathrm{pH}$ ranging from 5.5-5.7. The results of the $\mathrm{pH}$ analysis show that the soil developing from gabbro parent rock has a relatively higher soil $\mathrm{pH}$ when compared to the soil developing from phyllite and chert parent rock due to the nature of the parent rock, which is derived from alkaline igneous rocks. It is also seen from the $\mathrm{pH}$ value of the soil developing from Gabbro 2 parent rock, which is higher compared to the soil developing from Gabbro 1 rock parent because it is still not enough to decay and experience development or leaching so that it is still influenced by its parent rock properties which are alkaline.

\section{Exchangeable cations}

Exchangeable cations include sodium $(\mathrm{Na})$, potassium $(\mathrm{K})$, calcium $(\mathrm{Ca})$ and magnesium $(\mathrm{Mg})$, which are positively charged ions. These cations are important nutrients for plants. Generally, these cations are in a soil solution or in an exchange complex.

Exchangeable cations generally ranges from very low to low, except in the soil developing from Gabbro 1 parent rock that contains low $\left(5.19 \mathrm{cmol} \cdot \mathrm{kg}^{-1}\right)$ to moderate $\left(6.10-6.27 \mathrm{cmol}^{\mathrm{kg}}{ }^{-1}\right) \mathrm{Ca}$ and in the soil 
Table 3. Chemical properties of the soil developing from gabbro, phylitte and chert parent rock

\begin{tabular}{|c|c|c|c|c|c|c|c|c|}
\hline Parent rock & $\begin{array}{l}\text { Depth } \\
(\mathrm{cm})\end{array}$ & Horizon & $\begin{array}{c}\mathrm{pH} \\
\mathrm{H}_{2} \mathrm{O} \\
\end{array}$ & $\begin{array}{c}\mathrm{pH} \\
\mathrm{KCl} \\
\end{array}$ & $\begin{array}{c}\mathrm{Na} \\
\left(\mathrm{cmol}^{2} \mathrm{~kg}^{-1}\right) \\
\end{array}$ & $\begin{array}{c}\mathrm{K} \\
\left(\mathrm{cmol} \cdot \mathrm{kg}^{-1}\right) \\
\end{array}$ & $\begin{array}{c}\mathrm{Ca} \\
\left(\mathrm{cmol} \cdot \mathrm{kg}^{-1}\right)\end{array}$ & $\begin{array}{c}\mathrm{Mg} \\
\left(\mathrm{cmol} . \mathrm{kg}^{-1}\right)\end{array}$ \\
\hline \multirow{4}{*}{ Gabbro 1} & $0-17$ & $\mathrm{~A}$ & 6.0 & 4.1 & 0.07 & 0.08 & 5.19 & 0.18 \\
\hline & $17-42$ & $\mathrm{AB}$ & 6.4 & 4.0 & 0.10 & 0.04 & 6.27 & 0.17 \\
\hline & $42-75$ & Bt1 & 6.3 & 4.2 & 0.12 & 0.03 & 6.10 & 0.17 \\
\hline & $75-185$ & Bt2 & 6.4 & 4.1 & 0.13 & 0.03 & 6.24 & 0.16 \\
\hline \multirow{4}{*}{ Gabbro 2} & $0-14$ & $\mathrm{Bw}$ & 6.3 & 4.1 & 0.06 & 0.05 & 8.85 & 0.20 \\
\hline & $14-39$ & $\mathrm{BC} 1$ & 6.6 & 4.0 & 0.08 & 0.08 & 6.35 & 0.18 \\
\hline & $39-74$ & $\mathrm{BC} 2$ & 6.3 & 3.9 & 0.09 & 0.08 & 6.99 & 0.19 \\
\hline & $74-105$ & $\mathrm{BC} 3$ & 6.6 & 3.9 & 0.07 & 0.15 & 6.28 & 0.18 \\
\hline \multirow{4}{*}{ Phyllite 1} & $0-25$ & A & 5.0 & 3.9 & 0.05 & 0.10 & 3.54 & 0.17 \\
\hline & $25-51$ & $\mathrm{Bt}$ & 5.0 & 3.9 & 0.03 & 0.15 & 3.47 & 0.16 \\
\hline & $51-94$ & $\mathrm{BC} 1$ & 5.3 & 4.0 & 0.03 & 0.16 & 3.61 & 0.16 \\
\hline & 94-103 & $\mathrm{BC} 2$ & 5.5 & 3.9 & 0.04 & 0.17 & 3.57 & 0.17 \\
\hline \multirow{3}{*}{ Phyllite 2} & $0-20$ & A & 5.0 & 3.9 & 0.03 & 0.18 & 3.18 & 0.14 \\
\hline & $20-42$ & $\mathrm{Bw}$ & 5.3 & 4.0 & 0.02 & 0.13 & 3.23 & 0.15 \\
\hline & $42-62$ & $\mathrm{BC}$ & 5.2 & 4.0 & 0.03 & 0.10 & 3.33 & 0.15 \\
\hline \multirow{4}{*}{ Chert 1} & $0-20$ & $\mathrm{~A}$ & 5.7 & 4.0 & 0.04 & 0.11 & 4.35 & 0.16 \\
\hline & $20-74$ & Bw1 & 5.1 & 4.0 & 0.04 & 0.08 & 4.15 & 0.16 \\
\hline & $74-146$ & Bw2 & 5.4 & 4.0 & 0.03 & 0.05 & 3.98 & 0.16 \\
\hline & $146-162$ & Bw3 & 6.2 & 5.4 & 0.10 & 0.05 & 4.01 & 0.13 \\
\hline \multirow{4}{*}{ Chert 2} & $0-24$ & $\mathrm{~A}$ & 5.7 & 4.9 & 0.05 & 0.13 & 4.16 & 0.16 \\
\hline & $24-77$ & Bw1 & 5.6 & 4.8 & 0.06 & 0.16 & 4.35 & 0.16 \\
\hline & $77-110$ & Bw2 & 5.6 & 4.6 & 0.04 & 0.09 & 4.67 & 0.15 \\
\hline & $110-147$ & Bw3 & 5.5 & 4.0 & 0.04 & 0.06 & 4.80 & 0.17 \\
\hline
\end{tabular}

developing from Gabbro 2 parent rock with moderate

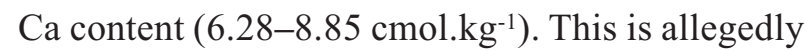
derived from the residual weathering of the parent rock, which is gabbro rock that contains lots of $\mathrm{Ca}$.

\section{Cation exchange capacity (CEC)}

Cation exchange capacity (CEC) is the ability of the soil to hold and exchange cations. Soil with high CEC has the power to store high nutrients (Hardjowigeno, 1993). Therefore, CEC plays a large role in nutrient absorption by plants, soil fertility, nutrient retention and fertilizer application (Tan, 2011). Cation exchange capacity is determined by the content of organic matter and the number and type of clay minerals in the soil.

CEC of the soil developing from Gabbro 1 parent rock is in moderate criteria $\left(18.4-22.2 \mathrm{cmol}_{\mathrm{kg}} \mathrm{k}^{-1}\right)$, while CEC of the soil developing from Gabbro 2 parent rock ranges from low $\left(11.8-16.8 \mathrm{cmol} . \mathrm{kg}^{-1}\right)$ to medium $\left(19.5 \mathrm{cmol}^{\mathrm{kg}} \mathrm{k}^{-1}\right)$. Soil developing from Phyllite 1 and 2 and Chert 1 and 2 has a low soil CEC. This is presumably because it is influenced by the type of clay and soil organic matter content.
CEC of the soil developing from Gabbro 1 parent rock is categorized in the moderate criteria, while the CEC of the soil developing from Gabbro 2 parent rock is included in the low to moderate criteria. This is because the clay content in the soil developing from Gabbro 1 parent rock is higher than that from Gabbro 2. Soils developing from Phyllite 1, Phyllite 2, Chert 1 and Chert 2 parent rocks contain quite high clays, however, this low CEC is allegedly due to the effect of low soil $\mathrm{pH}$.

\section{Base saturation}

Base saturation is an indicator of soil fertility. Base cations are generally easily washed away, so that the soil with high base saturation indicates that the soil has not been frequently washed and is fertile soil (Hardjowigeno, 1993).

Base saturation of the soil developing from Gabbro 1 parent rock ranges from low $(25-33 \%)$ to moderate (36\%), while that from Gabbro 2 ranges from moderate (39-47\%) to high (62\%). Base saturation of the soil developing from Phyllite 1 parent rock ranges from low (35\%) to moderate (36-41\%), 
Table 4. Chemical properties of the soil developing from gabbro, phylitte and chert parent rock

\begin{tabular}{|c|c|c|c|c|c|c|c|}
\hline $\begin{array}{l}\text { Parent } \\
\text { material }\end{array}$ & $\begin{array}{l}\text { Depth } \\
(\mathrm{cm})\end{array}$ & Horizon & 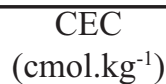 & $\begin{array}{l}\mathrm{BS} \\
(\%)\end{array}$ & $\begin{array}{c}\text { P-Available } \\
\left(\mathrm{mg}^{2} \mathrm{~kg}^{-1}\right)\end{array}$ & $\begin{array}{c}\text { C-Organic } \\
(\%)\end{array}$ & $\begin{array}{c}\text { N-Total } \\
(\%)\end{array}$ \\
\hline \multirow{4}{*}{ Gabbro 1} & $0-17$ & A & 22.2 & 25 & 5 & 2.7 & 0.10 \\
\hline & $17-42$ & $\mathrm{AB}$ & 20.0 & 33 & 4 & 1.4 & 0.04 \\
\hline & $42-75$ & Bt1 & 18.0 & 36 & 5 & 1.7 & 0.04 \\
\hline & $75-185$ & Bt2 & 18.4 & 36 & 4 & 1.1 & 0.06 \\
\hline \multirow{4}{*}{ Gabbro 2} & $0-14$ & $\mathrm{Bw}$ & 19.5 & 47 & 10 & 2.2 & 0.05 \\
\hline & $14-39$ & $\mathrm{BC} 1$ & 16.8 & 39 & 8 & 1.1 & 0.03 \\
\hline & 39-74 & $\mathrm{BC} 2$ & 11.8 & 62 & 10 & 1.3 & 0.03 \\
\hline & $74-105$ & $\mathrm{BC} 3$ & 15.4 & 43 & 6 & 1.1 & 0.02 \\
\hline \multirow{4}{*}{ Phyllite 1} & $0-25$ & A & 10.8 & 36 & 5 & 2.6 & 0.09 \\
\hline & $25-51$ & $\mathrm{Bt}$ & 10.7 & 36 & 6 & 1.8 & 0.07 \\
\hline & $51-94$ & $\mathrm{BC} 1$ & 9.6 & 41 & 5 & 1.3 & 0.06 \\
\hline & 94-103 & $\mathrm{BC} 2$ & 10.7 & 37 & 9 & 1.8 & 0.08 \\
\hline \multirow{3}{*}{ Phyllite 2} & $0-20$ & A & 8.4 & 40 & 5 & 2.5 & 0.21 \\
\hline & $20-42$ & $\mathrm{Bw}$ & 8.6 & 39 & 7 & 1.8 & 0.10 \\
\hline & $42-62$ & $\mathrm{BC}$ & 8.0 & 40 & 8 & 1.5 & 0.22 \\
\hline \multirow{4}{*}{ Chert 1} & $0-20$ & $\mathrm{~A}$ & 9.2 & 45 & 6 & 2.9 & 0.06 \\
\hline & $20-74$ & Bw1 & 10.7 & 38 & 7 & 2.7 & 0.17 \\
\hline & $74-146$ & Bw2 & 10.0 & 43 & 6 & 2.5 & 0.25 \\
\hline & $146-162$ & Bw3 & 7.4 & 59 & 8 & 2.7 & 0.16 \\
\hline \multirow{4}{*}{ Chert 2} & $0-24$ & A & 7.0 & 62 & 6 & 4.2 & 0.23 \\
\hline & $24-77$ & Bw1 & 6.6 & 66 & 7 & 3.1 & 0.16 \\
\hline & $77-110$ & Bw2 & 6.3 & 78 & 7 & 2.3 & 0.17 \\
\hline & $110-147$ & Bw3 & 6.2 & 42 & 5 & 2.3 & 0.18 \\
\hline
\end{tabular}

while that from Phyllite 2 parent rock is moderate (39-40\%). Base saturation of the soil developing from Chert 1 parent rock ranges from moderate (38$45 \%$ ) to high (59\%), while that from Chert 2 ranges from moderate (42\%), high (62-66\%) and very high (78\%). Base saturation of the soil developing from Gabbro 1 parent rock is low to moderate because most of the bases have been leached, especially $\mathrm{Na}$, $\mathrm{K}$ and $\mathrm{Mg}$, while the soil CEC value is higher. Base saturation of the soil developing from Gabbro 2 parent rock ranges from moderate to high because this soil has not experienced weathering and soil development so that the alkaline content, especially $\mathrm{Ca}$, that comes from weathering of parent rock is still quite high.

Base saturation of the soil developing from Phyllite 1 parent rock ranges from low to moderate. This is because this soil developed sufficiently so that many bases had been leached. Meanwhile, Base saturation of the soil developing from Phyllite 2 parent rock has a moderate value because this soil has not developed enough so that the content of exchangeable cations, especially $\mathrm{K}$, originated from the weathering of rich parent rock is still quite high.

Base saturation of the soil developing from Chert 1 parent rock ranges from moderate to high. Meanwhile, base saturation of the soil developing from Chert 2 parent rock ranges between medium, high and very high. Both of these soils are new soils that have slightly developed, thus not many base cations are leached. Base saturation of the soil developing from Chert 2 parent rock is greater than that from Chert 1 because the soil CEC is lower.

\section{P-Available}

Phosphorus (P) is a type of nutrient that is very important for plants included in macro nutrients. $\mathrm{P}$ in the soil comes from organic matter and weathering minerals such as apatite and synthetic fertilizer.

The available $P$ content of the soil developing from Gabbro, Phyllite and Chert parent rock is generally very low. This is due to the low content of $\mathrm{P}$, intensive leaching and the possibility of fixation by $\mathrm{Al}$ and $\mathrm{Fe}$ in the soil parent rocks. 


\section{C-Organic}

C-Organic content is an indicator of the presence of organic matter in the soil. The content of organic matter affects other soil properties. Organic matter indirectly affects the speed of biochemical reactions in the soil through heat absorption, where soils containing lots of organic matter are usually dark so that they absorb heat more quickly. The organic material is a cementing material or adhesive of soil particles so that it can form certain aggregates or structures.

Organic $\mathrm{C}$ content of the soil developing from gabbro and phyllite parent rocks ranges from low to moderate. This is because the soils developing from Gabbro1, Gabbro 2 and Phyllite 2 parent rocks are located on forested land with pine vegetation with fairly shaded cover so that weathering of organic matter runs very slowly. In addition, pine plants contain a lot of silicate that are difficult to decompose, thus the soil contains fewer nutrients. Meanwhile, the soil developing from Phyllite 1 parent rock is used to cultivate cassava, and the soil surface condition is quite open so that organic matter quickly decomposes and degenerates, resulting in a low organic matter content in the soil. Organic C content of the soil developing from chert parent rock is generally moderate to high because it is located on land that is used as a mixed plantation including teak, cassava, bananas and so on. Variation in vegetation causes plants to get enough light and contribute organic matter to the soil. Th organic $\mathrm{C}$ content of the soil is derived not only from the weathering of the vegetation litter, but also from the weathering of rocks containing micro-organisms.

\section{N-Total}

Nitrogen is one of the nutrients that has an important role for plants that is included in the macro nutrient. The main source of $\mathrm{N}$ in the soil is organic matter. Apart from organic matter, these nutrients come from the atmosphere through the process of $\mathrm{N}$ fixation by microorganisms.

Total $\mathrm{N}$ of the soil developing from Gabbro 1 parent rock ranges from very low to low. Total $\mathrm{N}$ of the soil developing from Gabbro 2 and Phyllite 1 parent rocks are very low. This is because the decomposition of organic matter is slow or very slow. Meanwhile, Total $\mathrm{N}$ of the soil developing from Phyllite 2 and Chert 1 parent rock ranges from low to moderate and between very low, low and medium, respectively. Meanwhile, total $\mathrm{N}$ of the soil developing from Chert 2 is low to moderate. This is because the amount of soil organic matter is greater so that it encourages the activity of the transformer organisms to become active. Some $\mathrm{N}$ change shape, so it is easily lost from the body of the soil. This causes the total $\mathrm{N}$ content to vary in the soil.

\section{Soil Management}

Soil management is based on the soil characteristics in terms of morphology, physics and chemistry (Nurdin, 2012). The soil, which is the object of this research, develops from three types of parent rock, namely gabbro, phyllite and chert that generally have a high fertility rate, however, it is necessary to take several management actions so that the soil can provide optimal growth factors for the plants. Soil developing from Gabbro 1 parent rock has a fairly high clay content so that it becomes more dense, thereby affecting the development of plant roots. To overcome this, it is necessary to add organic matter so that the soil becomes crumblier. Soils developing from Phyllite 1 and 2 parent rocks have acidic $\mathrm{pH}$ while the soils developing from Chert 1 and 2 are slightly acidic. Soil acidity can be overcome by adding lime, and it will be better if accompanied by the addition of organic matter as one way to increase the soil CEC. The addition of organic matter and lime is also expected to increase the soil base saturation, especially in the soil developing from Gabbro 1 and phyllite parent rocks. Organic matter plays a major role in the availability of nutrients in the soil (Sarkar et al., 2014) The addition of organic matter can be in the form of organic fertilizer or in the form of planting cover crops because all of the soils under study are in areas with high levels of damage. The results of the studies of Tarigan and Mardiatno (2012) showed that slope has high to very high effect on soil loss. Planting ground cover crops can reduce erosion rates as well as increasing soil organic matter content.

\section{CONCLUSIONS}

The order of clay content of the soil developed from Gabbro, Phyllite and Chert parent rock, from the highest to the lowest, is as follows: Gabbro 1> Chert $1>$ Phyllite $1>$ Chert $2>$ Phyllite $2>$ Gabbro 2 . Meanwhile, the order of soil acidity $(\mathrm{pH})$ from the highest to the lowest is as follows: Gabbro $2>$ Gabbro $1>$ Chert $1 \sim$ Chert $2>$ Phyllite $1 \sim$ Phyllite 2 . The order of CEC of the soil developed from Gabbro, Phyllite and Chert parent rock, from the highest to the lowest, is as follows: Gabbro 1> Gabbro 2> 
Phyllite1 $>$ Chert $1>$ Phyllite $2>$ Chert 2, and the order of base saturation of the soil developed from Gabbro, Phyllite and Chert parent rock is Chert 2> Gabbro 2> Chert $1>$ Phyllite $2>$ Phyllite1 $>$ Gabbro1.

\section{REFERENCES}

Damm, A., E. Paul-Limoges, E. Haghighi, C. Simmer, F. Morsdorf, F.D. Schneider, C. van der Tol, M. Migliavacca, and U. Rascher. 2018. Remote sensing of plant-water relations: An overview and future perspectives. Journal of Plant Physiology, 227: 2-19.

Sarkar, D., D.K.De, R. Das and B. Mandal. 2014. Removal of organic matter and oxides of iron and manganese from soil influences boron adsorption in soil. Geoderma, 214: 213-216.

Harahsheh, H.; M. Mashroom; Y. Marzouqi; E. Al Khatib; B.R.M. Rao, and M.A. Fyzee. 2013. Soil thematic map and land capability classification in dubai emirate, p. 133-146. In: S.A. Shahid; F.K. Taha; and M.A. Abdelfattah (eds.). Developments in soil classification, land use planning and policy implications innovative thinking of soil inventory for land use planning and Management of land resources. Dordrecht Heidelberg New York London: Springer.

Hardjowigeno, S. 1993. Klasifikasi tanah dan pedogenesis, Jakarta: Akademi Pressindo.

Liu, Y., C. Subhash, J. Yan, C. Song, J. Zhao and J. Li. 2011. Maize leaf temperature responses to drought: Thermal imaging and quantitative trait loci (QTL) mapping. Environmental and Experimental Botany, 71: 158-165.
Nurdin. 2012. Morfologi, sifat fisik dan kimia tanah inceptisols dari bahan lakustrin paguyamangorontalo kaitannya dengan pengelolaan tanah. Jurnal Agroteknotropika, 1 : 13-22.

Paramitha, T.A. and D. Mardji. 2015. Growth responses of acacia mangium and paraserianthes falcataria seedlings on different soil origin under nursery condition. Aceh International Journal of Science and Technology, 4: 114-125.

Paton, T.R. 1978. The formation of soil material. 1st ed., London: George Allen and Unwin Ltd.

Sunarta I.N., I.N. Merit, N.M. Trigunasih dan T. Kusmawati, 2015. Peningkatan produksi pangan pada lahan sawah dengan penerapan pemupukan hara spesifik lokasi (PHSL) melalui evaluasi status unsur hara tanah. Fakultas Pertanian Universitas Udayana Denpasar Bali-Indonesia. Agrotrop, 5: 187-193.

Tan, K.H. 2011. Principles of soil chemistry. 4th ed., USA: CRC Press Taylor and Francis Group, LLC.

Tarigan, D.R. dan D. Mardiatno. 2012. Pengaruh erosivitas dan topografi terhadap kehilangan tanah pada erosi alur di daerah aliran sungai secang desa hargotirto kecamatan kokap kabupaten kulonprogo. Jurnal Bumi Indonesia, 1: 411-420.

Zinck J.A.; G. Metternicht; G.Bocco and H.F. Del Valle. 2016. Presentation, p.1-6. In: Zinck J.A.: G. Metternicht: G.Bocco and H.F. Del Valle (eds.). Geopedology an integration of geomorphology and pedology for soil and landscape studies. Switzerland: Springer International Publishing. 